\title{
Evaluation of body appendage injuries to juvenile signal crayfish (Pacifastacus leniusculus): relationships and consequences
}

\author{
A. Kouba(1), M. Buřič $\breve{c}^{(1)}$, T. Policar ${ }^{(1)}$, P. Kozák ${ }^{(1)}$ \\ Received November 1, 2010 \\ Revised January 14, 2011 \\ Accepted February 10, 2011
}

Key-words: antennae, autotomy, intraspecific interaction, regeneration, walking leg

\section{ABSTRACT}

Aggressive behaviour occurs frequently in crayfish and commonly results in injuries to body appendages. This study aimed to evaluate injuries to antennae, chelae, and walking legs of juvenile signal crayfish after seven months of rearing at high stocking density. We suggest that the high incidence of antennae injuries $(66.8 \%)$ is related to their delicate structure and exposed position, which makes them vulnerable to damage. Chelae were more frequently injured (45.5\%) than walking legs (7.8-23.6\%). Considering the robustness of these structures and the scarcity of animals with both chelae missing and/or regenerating (4.9\%), it seemed that injured animals were often killed by less injured ones. Antennae of crayfish with a single injured chela were more frequently injured on the side of the body with the damaged chela, and a similar pattern was observed for walking legs. Expanding on previous research reporting a negative relationship only between incidence of chela injury and crayfish size, we found this relationship to be significant for all evaluated appendages. We hypothesize that any injury and accompanying regeneration may have significant impact on subsequent injuries, overall growth, and reproductive success, and may result in death through cannibalism.

\section{RÉSUMÉ}

\section{Évaluation des blessures aux appendices de juvéniles d'écrevisse signal (Pacifastacus leniusculus) : relations et conséquences}

Mots-clés : antenne, autotomie, interaction intraspécifique, régénération, pattes
Le comportement agressif est fréquent chez l'écrevisse. II aboutit souvent à des blessures aux appendices. Cette étude évalue les blessures aux antennes, pinces et pattes de juvéniles d'écrevisse signal après sept mois d'élevage à forte densité. Nous suggérons que la fréquence élevée des blessures aux antennes $(66,8 \%)$ est en relation avec leur structure fragile et leur position exposée, qui les rendent plus vulnérables aux blessures. Les pinces sont plus souvent endommagées $(45,5 \%)$ que les pattes $(7,8-23,6 \%)$. Considérant la robustesse de ces structures et la rareté des animaux auxquels les deux pinces manquent et/ou sont en régénération (4,9\%), il semble que les animaux blessés sont souvent tués par moins blessés qu'eux. Les antennes des écrevisses avec une seule pince blessée sont plus souvent blessées du même côté que celui de la pince

(1) University of South Bohemia in České Budĕjovice, Faculty of Fisheries and Protection of Waters, South Bohemian Research Center of Aquaculture and Biodiversity of Hydrocenoses and Research Institute of Fish Culture and Hydrobiology, Zátiši 728/II, 38925 Vodn̆any, Czech Republic, koubaa00@vurh.jcu.cz 
endommagée et un schéma similaire est observé pour les pattes. En s'appuyant sur de précédentes recherches relatant une relation négative uniquement entre la fréquence des blessures aux pinces et la taille de l'écrevisse, nous trouvons cette relation également pour tous les appendices étudiés. Nous supposons que chaque blessure ou régénération liée peut avoir un impact significatif sur les dommages ultérieurs, croissance et succès reproductif et peut résulter en la mort par cannibalisme.

\section{INTRODUCTION}

Crayfish have a body plan typical of higher crustaceans with specialized appendages and associated structures (Holdich, 2002). Chelae, which perform several functions, are considered among the most important. They are used in mating (Snedden, 1990; Reynolds, 2002), defence against predators (Roth and Kitchell, 2005), inter- and intra-specific interactions (Garvey and Stein, 1993; Bergman and Moore, 2003; Kozák et al., 2007), and, to some extent, capture and manipulation of prey (Keller and Hazlett, 1996). In addition, male chelae are equipped with sensory structures that aid in the discrimination and localization of female scent (Belanger and Moore, 2006, 2009; Belanger et al., 2008).

Chelae can be lost during antagonistic encounters and reproductive activities (Kawai et al., 1994). Additional factors influencing the incidence of chelae loss may be the density of animals (Savolainen et al., 2004; Ramalho et al., 2008) and composition of bottom substrate (Savolainen et al., 2003) as well as availability of shelter and food (Capelli and Hamilton, 1984; Bergman and Moore, 2003). Aggressive interactions are reduced in an environment with high habitat complexity (Corkum and Cronin, 2004; Baird et al., 2006), which should result in lower frequency of injured crayfish.

Antennae are important in mediating social interactions (Rutherford et al., 1996; Horner et al., 2008) during which hierarchies of dominance are established (Bruski and Dunham, 1987; Cook and Moore, 2009). Antennae are essential for gaining tactile information for sensing the local topography (Basil and Sandeman, 2000; Koch et al., 2006), and for localizing food and conspecifics (Giri and Dunham, 1999, 2000). Agonistic behaviour and mechanical grading processes used by crayfish farmers often lead to damage to antennae (Ahvenharju and Ruohonen, 2007; Patullo et al., 2009).

Injury and accompanying regeneration to body appendages is usually considered from a cost/benefit viewpoint. On one hand, this process increases the chance of survival by facilitating escape. On the other, loss of part of the body can lead to local tissue damage, loss of body fluids, and infection (Bely and Nyberg, 2010). Furthermore, regeneration imposes an additional energy demand (regenerative load), reducing energy allocation for somatic and/or reproductive processes (Juanes and Smith, 1995; Powell et al., 1998; Mariappan et al., 2000). Crayfish with injured chelae have been found to be significantly smaller than intact individuals (Figiel and Miller, 1995; Savolainen et al., 2003).

Avoidance of injury, especially of antennae and chelae, is of crucial importance for crayfish. Despite the relatively extensive literature on loss and/or regeneration of crayfish chelae, little is known about injury to antennae and walking legs (2nd-5th pair of pereopods). This study aimed to evaluate injuries to antennae, chelae, and walking legs in signal crayfish (Pacifastacus leniusculus) juveniles after seven months of rearing at high stocking density. Possible relationships in patterns of appendage damage are outlined and discussed.

\section{MATERIALS AND METHODS}

\section{> ANIMALS AND REARING CONDITIONS}

On June 15th 2009, independent $P$. leniusculus larvae (2nd developmental stage) were placed in a plastic tank $\left(200 \mathrm{~L}\right.$, bottom area $\left.1.37 \mathrm{~m}^{2}\right)$ containing static water. The initial stocking 
density exceeded 1000 crayfish $\cdot \mathrm{m}^{-2}$, but exact numbers were not established. The tank was cleaned daily, and one third of its water volume was replaced with tempered tap water. Crossholed bricks provided an excess of shelters. Crayfish were fed ad libitum by size-graded pond zooplankton followed by frozen larvae of Chironomus plumosus and grated carrot. Final stocking density, after seven months, was 281 individuals $\mathrm{m}^{-2}$.

\section{> DATA COLLECTION}

At the end of the rearing period, crayfish were examined for loss and regeneration of body appendages: antennae, chelae, and walking legs (2nd-5th pair of pereopods), for each body side. Appendages were recorded as injured (damaged) if they were missing or regenerated. Uninjured appendages were used for comparison, and regeneration was considered evident when appendages were less than $80 \%$ their original size. After determination of sex, postorbital carapace length (POCL, measured from the edge of the eye socket to the posterior edge of the cephalothorax) was determined to the nearest $0.1 \mathrm{~mm}$ with a digital calliper (Schut Geometrical Metrology, Groningen, The Netherlands) according to the recommendation of Burič et al. (2010).

\section{> STATISTICAL ANALYSIS}

Data were analyzed using Statistica 8.0 (StatSoft, Inc.). Numbers of surviving females and males, as well as occurrence of injured appendages on right or left side were compared by contingency tables $\left(\chi^{2}\right)$. Growth values between sexes were tested with Student's $t$-test after assessing for normality and homoskedasticity with Kolmogorov-Smirnov and Levene's tests, respectively. Crayfish were divided into four groups, based on the injuries to chelae as follows: crayfish with both chelae intact $(\mathrm{RC}+\mathrm{LC}+)$; with right intact and lacking or with regenerating left chela $(\mathrm{RC}+\mathrm{LC}-)$; with left intact and lacking or with regenerating right chela $(\mathrm{RC}-\mathrm{LC}+)$; and lacking and/or with regenerating right and left chelae (RC-LC-). Occurrence of intact and damaged body appendages were represented by zeros and ones, respectively. As there were no divergences in loss and regeneration to any of body appendages between sexes (using Mann-Whitney $U$ test), data from both sexes were pooled for analysis. Percentages of lost or regenerating appendages between and within groups were analysed by Kruskall-Wallis. Multiple comparisons of mean ranks for all groups were used as a post hoc test. Growth values among groups in both sexes were assessed with these nonparametric tests because of heteroscedasticity in data (homogeneity of variance was assessed with Levene's test). Spearman rank correlations were used for evaluation of the relationship between occurrence of injured body appendages and size (POCL). The null hypothesis was rejected at $\alpha=0.05$. Data are expressed as means \pm SD.

\section{RESULTS}

There were no significant differences in numbers of males and females either in particular groups or in total $\left(\chi^{2}=0.58, \mathrm{df}=1, p=0.4\right)$ (Table I). More than a half of all animals $(54.5 \%)$ exhibited intact chelae. Among those with unilateral chela injury, no difference in right and left side injuries was noted $\left(\chi^{2}=0.23, \mathrm{df}=1, p=0.6\right)$. Occurrence of bilaterally affected crayfish was relatively rare $(4.9 \%)$ (Table I).

Antennae were the most common of injured appendages (66.8\% incidence), followed by chelae $(45.5 \%)$, and the 5th pair of pereopods $(23.6 \%)$. Incidence of injury in the second pair of pereopods was low (7.8\%) (Table II).

A high incidence of injured antennae (86.8\%) was recorded in crayfish without, or with regenerating, chelae. Both antennae were damaged in one third of the animals having both chelae intact (Table III). Antennae were more frequently injured on the body side with missing 


\section{Table I}

Numbers of male and female signal crayfish with both chelae $(R C+L C+)$, with right and without or with regenerating left chela $(R C+L C-)$, without or with regenerating right and with left chela $(R C-L C+)$, and without and/or with regenerating right and left chelae (RC-LC-) after seven months of rearing at high stocking density.

\section{Tableau I}

Nombre de mâles et de femelles d'écrevisse signal avec les deux pinces (RC+LC+), avec la pince droite et sans pince gauche ou en régénération ( $\mathrm{RC}+\mathrm{LC}-$ ), avec la pince gauche et sans pince droite ou en régénération ( $\mathrm{RC}-\mathrm{LC}+$ ), avec les deux pinces absentes ou en régénération (RC-LC-) après sept mois d'élevage en forte densité.

\begin{tabular}{|l|l|l|l|l|l|}
\hline Sex & $\mathrm{RC}+\mathrm{LC}+$ & $\mathrm{RC}+\mathrm{LC}-$ & $\mathrm{RC}-\mathrm{LC}+$ & $\mathrm{RC}-\mathrm{LC}-$ & Total \\
\hline Males & $103^{\mathrm{a}}$ & $40^{\mathrm{a}}$ & $35^{\mathrm{a}}$ & $7^{\mathrm{a}}$ & $185^{\mathrm{a}}$ \\
\hline Females & $107^{\mathrm{a}}$ & $41^{\mathrm{a}}$ & $40^{\mathrm{a}}$ & $12^{\mathrm{a}}$ & $200^{\mathrm{a}}$ \\
\hline Both & $210(54.5 \%)$ & $81(21.0 \%)$ & $75(19.5 \%)$ & $19(4.9 \%)$ & 385 \\
\hline
\end{tabular}

Values with the same superscript in columns are not significantly different (contingency tables, $p \leqslant 0.05$ ).

\section{Table II}

Percent of animals with lost or with regenerating body appendages (antennae, chelae, 2nd, 3rd, 4th, and 5 th pair of pereopods) in juvenile signal crayfish after seven months of rearing at high stocking density $(n=385)$.

\section{Tableau II}

Pourcentage de juvéniles d'écrevisse signal avec perte d'appendices ou en régénération (antennes, pinces, $2^{e}, 3^{e}, 4^{e}$ et $5^{e}$ paires de péréiopodes) après sept mois d'élevage en forte densité $(n=385)$.

\begin{tabular}{|l|c|}
\hline Appendix & Percent \\
\hline Antennae & 66.8 \\
\hline Chelae & 45.5 \\
\hline 2nd pereopods & 7.8 \\
\hline 3rd pereopods & 16.9 \\
\hline 4th pereopods & 16.9 \\
\hline 5th pereopods & 23.6 \\
\hline
\end{tabular}

or regenerating chelae in both RC+LC- and RC-LC+ groups $\left(\chi^{2}=9.56\right.$, df $=1, p=0.002$ and $\chi^{2}=4.15$, df $=1, p=0.04$, respectively). No differences were found within and between groups in pereopod injuries. This model was not evident for particular pereopods, but when numbers of injured walking legs were pooled, more left walking legs were affected than those on the right in $\mathrm{RC}+\mathrm{LC}-$ crayfish $\left(\chi^{2}=4.07, \mathrm{df}=1, p=0.04\right)$. This tendency was noted also for $\mathrm{RC}-\mathrm{LC}+$ group but was not significant $\left(\chi^{2}=1.29 \mathrm{df}=1, p=0.26\right)$ (Table III). The incidence of missing or regenerating pereopods consistently showed a positive relationship to the body side on which injured chela occurred.

The general pattern of males larger than females was confirmed $(t=3.60, p=0.0004)$ (Table IV). This was found in the RC+LC+ group as well as in the RC-LC-group $(t=3.36$, $p=0.0009$ and $t=2.49, p=0.02$, respectively). It has been stated (Figiel and Miller, 1995; Savolainen et al., 2003) that chelae injuries to crayfish result in their smaller size, as found in the RC+LC- and RC-LC+ males ( $p=0.01$ and $p=0.01$, respectively). This was not found in the male RC-LC- group. Females tended to follow a similar size pattern, but this trend was not significant in the RC+LC- and RC-LC+ groups compared to the RC+LC+ female group ( $p=0.18$ and $p=0.36$, respectively). However, size differences between RC+LC+ and RC-LC- females were significant $(p=0.02)$. Similarly, for all evaluated appendages, incidence of injury was negatively correlated with crayfish size (Table V). Larger crayfish had a lower incidence of injury than smaller ones. 


\section{Table III}

Percent of lost or regenerating body appendages (antennae, 2nd, 3rd, 4th, and 5th pair of pereopods) on the right $(R)$ and left $(L)$ body sides of signal crayfish with both chelae $(R C+L C+)$, with right and without or with regenerating left chela $(R C+L C-)$, without or with regenerating right and with left chela $(R C-L C+)$, and without and/or with regenerating right and left chelae (RC-LC-) after seven months of rearing at high stocking density.

\section{Tableau III}

Pourcentage de juvéniles d'écrevisse signal avec perte d'appendices ou en régénération (antennes, pinces, $2^{\mathrm{e}}, 3^{\mathrm{e}}, 4^{\mathrm{e}}$ et $5^{\mathrm{e}}$ paires de péréiopodes) sur le côté droit $(\mathrm{R})$, le gauche $(\mathrm{L})$, avec la pince droite et sans pince gauche ou en régénération ( $\mathrm{RC}+\mathrm{LC}-$ ), avec la pince gauche et sans pince droite ou en régénération ( $\mathrm{RC}-\mathrm{LC}+$ ), avec les deux pinces absentes ou en régénération (RC-LC-) après sept mois d'élevage en forte densité.

\begin{tabular}{|l|c|c|c|c|c|}
\multicolumn{1}{c|}{} & & $\mathrm{RC}+\mathrm{LC}+$ & $\mathrm{RC}+\mathrm{LC}-$ & $\mathrm{RC}-\mathrm{LC}+$ & $\mathrm{RC}-\mathrm{LC}-$ \\
\hline Antennae & $\mathrm{R}$ & $34.8^{\mathrm{aB}}$ & $33.3^{\mathrm{aB}}$ & $70.7^{\mathrm{bC}}$ & $89.5^{\mathrm{bB}}$ \\
& $\mathrm{L}$ & $31.9^{\mathrm{aB}}$ & $67.9^{\mathrm{bC}}$ & $45.3^{\mathrm{aBC}}$ & $84.2^{\mathrm{bB}}$ \\
\hline 2nd pereopods & $\mathrm{R}$ & $4.3^{\mathrm{aA}}$ & $1.2^{\mathrm{aA}}$ & $4.0^{\mathrm{aA}}$ & $10.5^{\mathrm{aA}}$ \\
& $\mathrm{L}$ & $2.9^{\mathrm{aA}}$ & $6.2^{\mathrm{aAB}}$ & $1.3^{\mathrm{aA}}$ & $15.8^{\mathrm{aA}}$ \\
\hline 3rd pereopods & $\mathrm{R}$ & $8.1^{\mathrm{aA}}$ & $9.9^{\mathrm{aAB}}$ & $14.7^{\mathrm{aAB}}$ & $15.8^{\mathrm{aA}}$ \\
& $\mathrm{L}$ & $5.7^{\mathrm{aA}}$ & $12.3^{\mathrm{aAB}}$ & $10.7^{\mathrm{aA}}$ & $10.5^{\mathrm{aA}}$ \\
\hline 4th pereopods & $\mathrm{R}$ & $6.7^{\mathrm{aA}}$ & $8.6^{\mathrm{aAB}}$ & $12.0^{\mathrm{aA}}$ & $21.1^{\mathrm{aA}}$ \\
& $\mathrm{L}$ & $7.1^{\mathrm{aA}}$ & $16.0^{\mathrm{aAB}}$ & $8.0^{\mathrm{aA}}$ & $21.1^{\mathrm{aA}}$ \\
\hline 5th pereopods & $\mathrm{R}$ & $12.9^{\mathrm{aA}}$ & $13.6^{\mathrm{aAB}}$ & $17.3^{\mathrm{aAB}}$ & $21.1^{\mathrm{aA}}$ \\
& $\mathrm{L}$ & $9.0^{\mathrm{aA}}$ & $18.5^{\mathrm{aAB}}$ & $16.0^{\mathrm{aAB}}$ & $10.5^{\mathrm{aA}}$ \\
\hline
\end{tabular}

Values with differing small and capital letters as superscripts are significantly different in rows and columns, respectively (multiple comparisons of mean ranks for all groups; $p \leqslant 0.05$ ).

\section{Table IV}

Size (presented as postorbital carapace length in $\mathrm{mm}$ ) of surviving signal crayfish males and females with both chelae $(R C+L C+)$, with right and without or with regenerating left chela $(R C+L C-)$, without or with regenerating right and with left chela $(R C-L C+)$, and without and/or with regenerating right and left chelae (RC-LC-) after seven months of rearing at high stocking density.

\section{Tableau IV}

Taille (longueur postorbitale de la carapace en $\mathrm{mm}$ ) des écrevisses signal survivantes mâles et femelles avec la pince droite et sans pince gauche ou en régénération ( $\mathrm{RC}+\mathrm{LC}-$ ), avec la pince gauche et sans pince droite ou en régénération (RC-LC+), avec les deux pinces absentes ou en régénération (RC-LC-) après sept mois d'élevage en forte densité.

\begin{tabular}{|l|c|c|c|c|c|}
\hline Sex & RC+LC+ & RC+LC- & RC-LC+ & RC-LC- & Total \\
\hline Males & $14.06 \pm 1.71^{\mathrm{b} *}$ & $12.99 \pm 1.73^{\mathrm{a}}$ & $12.93 \pm 1.77^{\mathrm{a}}$ & $13.97 \pm 2.34^{\mathrm{b} *}$ & $13.61 \pm 1.82^{*}$ \\
\hline Females & $13.29 \pm 1.64^{\mathrm{b} *}$ & $12.67 \pm 1.31^{\mathrm{b}}$ & $12.76 \pm 2.04^{\mathrm{b}}$ & $11.88 \pm 1.37^{\mathrm{a} *}$ & $12.97 \pm 1.69^{*}$ \\
\hline
\end{tabular}

Values with differing superscripts in rows are significantly different (multiple comparisons of mean ranks for all groups; $p \leqslant 0.05$ ). Asterisked values refer to significant differences in columns (Student's $t$-test; $p \leqslant 0.05)$. Data are presented as means \pm SD.

\section{DISCUSSION}

When we considered the generally accepted rule that sex ratio of males to females is approximately $1: 1$ in crayfish populations (Reynolds, 2002) along with the more rapid growth of males with more developed dominancy and aggressiveness (Bruski and Dunham, 1987; Savolainen et al., 2003), it was surprising that this ratio did not change after seven months. This supports the suggestion of underdeveloped male dominancy over females during the juvenile period (Bovbjerg, 1956). However, a comprehensive view of intraspecific interactions between the sexes in juvenile crayfish is lacking (cf. Figler et al., 1999). We assume that, even in the case of emerging aggressive behaviour, males are more exposed to antagonistic encounters and 


\section{Table $V$}

Spearman rank correlations between size (postorbital carapace length) and occurrence of lacking or regenerating body appendages.

Tableau $\mathrm{V}$

Coefficients de corrélation de rang de Spearman entre la taille (longueur postorbitale de la carapace) et la fréquence des appendices manquants ou en régénération.

\begin{tabular}{|l|c|c|}
\multicolumn{1}{c|}{ Spearman rank correlation } & $p$ \\
\hline Antennae & -0.212 & $<0.05$ \\
\hline Chelae & -0.163 & $<0.05$ \\
\hline 2nd pereopods & -0.108 & $<0.05$ \\
\hline 3rd pereopods & -0.115 & $<0.05$ \\
\hline 4th pereopods & -0.115 & $<0.05$ \\
\hline 5th pereopods & -0.099 & $<0.05$ \\
\hline
\end{tabular}

females may spend more time in shelters. These patterns should have been reinforced by the availability of shelter and food in our conditions. However, there is currently no confirmed information about sex ratio in juvenile crayfish.

At present, only chela injuries have been reported to be a factor affecting survival and growth in crayfish (e.g. Hirvonen, 1992; Figiel and Miller, 1995; Savolainen et al., 2003). Information concerning injuries of other body appendages (antennae and walking legs), and their possible interrelationship, is lacking. We found that antennae were the most widely injured appendage (two thirds of all animals) even in the RC+LC+ group (33.3\% incidence), but they were damaged significantly more in case of RC-LC-crayfish $(86.8 \%)$. This is probably the consequence of their more fragile structure and exposed position (Holdich, 2002) making them vulnerable to damage by competitors, especially in crayfish with missing or regenerating chelae. The exposed position might, at least in a part, result in more injuries to the 5th pair of pereopods compared to other walking legs. Antennae and walking legs of crayfish with a single injured chela tended to be more injured on the body side on which a regenerating or no chela occurred. That suggests a prominent role of chelae in distribution of antennae and walking legs injuries.

The proportion of crayfish with non-injured chelae (54.5\%) was higher than that reported by González et al. (2010) who found a 41.5\% incidence of chelae injury in 391 surviving juveniles from an initial density 1000 crayfish $\cdot \mathrm{m}^{-2}$ after a 100 -day experiment. This may reflect decreasing frequency of chela injuries over time (see González et al., 2010) suggesting cannibalization of injured animals by intact ones together with regeneration of damaged appendages (Mason, 1979; Buřic et al., 2009). Higher levels of injury to chelae, which are relatively robust, along with lesser damage to the more fragile walking legs (Table II), suggests that cannibalism must occur relatively quickly, especially in cases of bilateral chela damage. Low abundance of the RC-LC- group supports this idea. However, this situation may alter at sexual maturity when mainly males are involved in more aggressive encounters.

Males grow faster than females, as has been described (Harlıoglu, 2009). It is interesting that the size of RC-LC- males was comparable to that of RC+LC+ males. Although the size of injured males should be carefully considered, because of their low abundance $(n=9)$, we assume that these relatively large males may have been losers in dominance encounters. Such injuries in crayfish are a possible outcome in the formation of dominant-subordinate relationships (Bruski and Dunham, 1987). It has been reported that crayfish with injured chelae are smaller than those with undamaged chelae (Hirvonen, 1992; Figiel and Miller, 1995; Savolainen et al., 2003). Expanding on previous research reporting a negative relationship between incidence of chela injury and crayfish size only, our results showed these significant relationships for any of the evaluated body appendages (Table V). Males are dominant and, consequently, more frequently injured than females (Gherardi, 2002); hence, inequality between sexes was expected with respect to body appendage injury. However, this was not observed in juveniles in our conditions, which concurs with the suggestions of Bovbjerg (1956) that intraspecific aggressive behaviour between sexes is not present in juvenile crayfish. 
We assume that an injury/size pattern does not apply only to damaged chelae, and that occurrence of injuries is correlated, involving all body appendages. Some damage had generally occurred even in $\mathrm{RC}+\mathrm{LC}+$ crayfish, but greater, side-dependent, injuries were present when one chela was damaged. Animals lacking, or with regenerating, chelae were particularly negatively affected.

The importance of antennae and chelae is well known, however the role of walking legs in locomotion, sensing and collection of food, cleaning of body surfaces, and mating and egg rolling (Pond, 1975; Holdich, 2002) should not be undervalued. The process of regeneration is relatively rapid and well developed in crayfish (McCall and Mead, 2008; Buřič et al., 2009); however, body part regeneration uses energy that would otherwise be available for somatic and/or reproductive processes (Aiken and Waddy, 1992; Juanes and Smith, 1995). Consequently, injuries and the accompanying regeneration may have a significant impact on overall growth, survival, and reproductive success in crayfish.

Although several patterns have been highlighted in this study, future research, supporting these findings needs to be conducted. Substantial attention should be given to direct observation of juvenile crayfish behaviour.

\section{ACKNOWLEDGEMENTS}

This study was supported financially by the Ministry of Agriculture of the Czech Republic (QH71305), by the Ministry of Education, Youth, and Sports of the Czech Republic (CZ.1.05/2.1.00/01.0024 and ME 10125), and by the Grant Agency of the University of South Bohemia (047/2010/Z). We also deeply appreciate the assistance of the Lucidus Consultancy for English correction of this manuscript.

\section{REFERENCES}

Ahvenharju T. and Ruohonen K., 2007. Agonistic behaviour of signal crayfish (Pacifastacus leniusculus Dana) in different social environments: Effect of size heterogeneity on growth and food intake. Aquaculture, 271, 307-318.

Aiken D.E. and Waddy S.L., 1992. The growth process in crayfish. Rev. Aquat. Sci., 6, 335-381.

Baird H.P., Patullo B.W. and Macmillan D.L., 2006. Reducing aggression between freshwater crayfish (Cherax destructor Clark: Decapoda, Parastacidae) by increasing habitat complexity. Aquac. Res., 37, 1419-1428.

Basil J. and Sandeman D., 2000. Crayfish (Cherax destructor) use tactile cues to detect and learn topographical changes in their environment. Ethology, 106, 247-259.

Belanger R.M. and Moore P.A., 2006. The use of the major chelae by reproductive male crayfish (Orconectes rusticus) for discrimination of female odours. Behaviour, 143, 713-731.

Belanger R.M. and Moore P.A., 2009. The role of the major chelae in the localization and sampling of female odours by male crayfish, Orconectes rusticus (Girard, 1852). Crustaceana, 82, 653-668.

Belanger R.M., Ren X., McDowell K.E., Chang S., Moore P.A. and Zielinski B.S., 2008. Sensory setae on the major chelae of male crayfish, Orconectes rusticus (Decapoda, Astacidae): Impact of reproductive state on function and distribution. J. Crust. Biol., 28, 27-36.

Bely A.E. and Nyberg K.G., 2010. Evolution of animal regeneration: re-emergence of a field. Trends Ecol. Evol., 25, 161-170.

Bergman D.A. and Moore P.A., 2003. Field observations of intraspecific agonistic behavior of two crayfish species, Orconectes rusticus and Orconectes virilis, in different habitats. Biol. Bull., 205, 26-35.

Bovbjerg R.V., 1956. Some factors affecting aggressive behavior in crayfish. Physiol. Zool., 29, 127-136.

Bruski C.A. and Dunham D.W., 1987. The importance of vision in agonistic communication of the crayfish Orconectes rusticus. I. An analysis of bout dynamics. Behaviour, 103, 83-107.

Buřič M., Kouba A. and Kozák P., 2009. Chelae regeneration in European alien crayfish Orconectes limosus (Rafinesque 1817). Knowl. Managt. Aquatic Ecosyst., 394-395, 04. 
Buřič M., Kouba A. and Kozák P., 2010. Molting and growth in relation to form alternations in the male spiny-cheek crayfish Orconectes limosus. Zool. Stud., 49, 28-38.

Capelli G.M. and Hamilton P.A., 1984. Effects of food and shelter on aggressive activity in the crayfish Orconectes rusticus (Girard). J. Crustac. Biol., 4, 252-260.

Cook M.E. and Moore P.A., 2009. Communication networks and loser effects interact to influence the outcome of aggressive interactions in the crayfish Orconectes rusticus. Behaviour, 146, 263-281.

Corkum L.D. and Cronin D.J., 2004. Habitat complexity reduces aggression and enhances consumption in crayfish. J. Ethol., 22, 23-27.

Figiel C.R. and Miller G.L., 1995. The frequency of chelae autotomy and its influence on the growth and survival of the crayfish Procambarus clarkii (Girard, 1852) (Decapoda, Cambaridae). Crustaceana, 68, 472-483.

Figler M.H., Cheverton H.M. and Blank G.S., 1999. Shelter competition in juvenile red swamp crayfish (Procambarus clarkii): the influences of sex differences, relative size, and prior residence. Aquaculture, 178, 63-75.

Garvey J.E. and Stein R.A., 1993. Evaluating how chela size influences the invasion potential of an introduced crayfish. Am. Midl. Nat., 129, 172-181.

Gherardi F., 2002. Behaviour. In: Holdich D.M. (ed.), Biology of freshwater crayfish, Oxford, Blackwell Science, 258-290.

Giri T. and Dunham D.W., 1999. Use of the inner antennule ramus in the localisation of distant food odours by Procambarus clarkii (Girard, 1852) (Decapoda, Cambaridae). Crustaceana, 72, 123-127.

Giri T. and Dunham D.W., 2000. Female crayfish (Procambarus clarkii (Girard, 1852)) use both antennular rami in the localization of male odour. Crustaceana, 73, 447-458.

González R., Celada J.D., González A., García V., Carral J.M. and Sáez-Royuela M., 2010. Stocking density for the intensive rearing of juvenile crayfish, Pacifastacus leniusculus (Astacidae), using Artemia nauplii to supplement a dry diet from the onset of exogenous feeding. Aquacult. Int., 18, 371-378.

Harlıoğlu M.M., 2009. A comparison of the growth and survival of two freshwater crayfish species, Astacus leptodactylus Eschscholtz and Pacifastacus leniusculus (Dana) under different temperature and density regimes. Aquacult. Int., 17, 31-43.

Hirvonen H., 1992. Effects of backswimmer (Notonecta) predation on crayfish (Pacifastacus) young: autotomy and behavioural responses. Ann. Zool. Fenn., 29, 262-271.

Holdich D.M., 2002. Background and functional morphology. In: Holdich D.M. (ed.), Biology of freshwater crayfish, Oxford, Blackwell Science, 3-29.

Horner A.J., Schmidt M., Edwards D.H. and Derby C.D., 2008. Role of the olfactory pathway in agonistic behavior of crayfish Procambarus clarkii. Invertebr. Neurosci., 8, 11-18.

Juanes F. and Smith L.D., 1995. The ecological consequences of limb damage and loss in decapod crustaceans: a review and prospectus. J. Exp. Mar. Biol. Ecol., 193, 197-223.

Kawai T., Hamano T. and Matsuura S., 1994. Cheliped loss of the Japanese crayfish, Cambaroides japonicus in a stream and a lake in Hokkaido, Japan. Suisanzoshoku, 42, 215-220.

Keller T. and Hazlett B.A., 1996. Mechanical use of crayfish chelae. Mar. Fresh. Behav. Physiol., 28, 149-162.

Koch L.M., Patullo B.W. and Macmillan D.M., 2006. Exploring with damaged antennae: do crayfish compensate for injuries? J. Exp. Biol., 209, 3226-3233.

Kozák P., Buřič M., Policar T., Hamáčková J. and Lepičová A., 2007. The effect of inter- and intra-specific competition on survival and growth rate of native juvenile noble crayfish Astacus astacus and alien spiny-cheek crayfish Orconectes limosus. Hydrobiologia, 590, 85-94.

Mariappan P., Balasundaram C. and Schmitz B., 2000. Decapod crustacean chelipeds: an overview. J. Biosciences, 25, 301-313.

Mason J.C., 1979. Effects of temperature, photoperiod, substrate and shelter on survival, growth and biomass accumulation of juvenile Pacifastacus leniusculus in culture. Freshw. Crayfish, 4, 73-82.

McCall J.R. and Mead K.S., 2008. Structural and functional changes in regenerating antennules in the crayfish Orconectes sanborni. Biol. Bull., 214, 99-110.

Patullo B.W., Bairda H.P. and Macmillan D.L., 2009. Altered aggression in different sized groups of crayfish supports a dynamic social behaviour model. Appl. Anim. Behav. Sci., 120, 231-237. 
Pond C.M., 1975. The role of the "walking legs" in aquatic and terrestrial locomotion of the crayfish Austropotamobius pallipes (Lereboullet). J. Exp. Biol., 62, 447-454.

Powell M.L., Hammer H.S. and Watts S.A., 1998. Observations on the frequency of claw loss in the crayfish Procambarus clarkii. J. World Aquacult. Soc., 29, 485-490.

Ramalho R.O., Correia A.M. and Anastácio P.M., 2008. Effects of density on growth and survival of juvenile red swamp crayfish, Procambarus clarkii (Girard), reared under laboratory conditions. Aquacult. Res., 39, 577-586.

Reynolds J.D., 2002. Growth and reproduction. In: Holdich D.M. (ed.), Biology of freshwater crayfish, Blackwell Science, Oxford, 152-191.

Roth B.M. and Kitchell J.F., 2005. The role of size-selective predation in the displacement of Orconectes crayfishes following rusty crayfish invasion. Crustaceana, 78, 297-310.

Rutherford P.L., Dunham D.W. and Allison V., 1996. Antennule use and agonistic success in the crayfish Orconectes rusticus. Crustaceana, 69, 117-122.

Savolainen R., Ruohonen K. and Tulonen J., 2003. Effects of bottom substrate and presence of shelter in experimental tanks on growth and survival of signal crayfish, Pacifastacus leniusculus (Dana) juveniles. Aquacult. Res., 34, 289-297.

Savolainen R., Ruohonen K. and Railo E., 2004. Effect of stocking density on growth, survival and cheliped injuries of stage 2 juvenile signal crayfish Pacifastacus leniusculus Dana. Aquaculture, $231,237-248$.

Snedden W.A., 1990. Determinants of male mating success in the temperate crayfish Orconectes rusticus: chela size and sperm competition. Behaviour, 115, 100-113. 